\title{
DESAIN PEMBELAJARAN STEM BERDASARKAN KEMAMPUAN 4C DI SEKOLAH DASAR
}

\author{
${ }^{1}$ Nida Oktapiani, ${ }^{2}$ Ghullam Hamdu \\ 1nidaoktapiani03@student.upi.edu, 22ghullamh2012@upi.edu \\ 1,2Universitas Pendidikan Indonesia Kampus Tasikmalaya
}

\begin{abstract}
ABSTRAK
Inovasi pembelajaran yang dilakukan di Sekolah Dasar masih belum optimal. Hal ini dilakukan karena pembelajaran di sekolah dasar umumnya masih menggunakan pembelajaran konvensional. Pembelajaran STEM dirancang sebagai salah satu alternatif inovasi yang dilakukan berdasarkan kurikulum yang dilakukan secara tematik. Rancangan desain pembelajaran STEM ini dikembangkan dalam bentuk Rencana Pelaksanaan Pembelajaran (RPP) untuk kelas VI Sekolah Dasar dengan menerapkan keterampilan 4C. Untuk mendapatkan RPP tersebut dilakukan penelitian dengan pendekatan qualitative reseach menggunakan metode Focus Group Discussion ( FGD). Data diperoleh melalui wawancara, observasi, studi dokumentasi, proses $F G D$. Wawancara, observasi dan dokumentasi dilakukan untuk mendapatkan informasi awal mengenai desain pembelajaran yang sering digunakan guru di SD. Sedangkan FGD dilakukan melalui diskusi kelompok dengan tujuan untuk memvalidasi pengembangan perangkat pembelajaran STEM. Hasil yang didapat berupa desain pembelajaran STEM berdasarkan kemampuan $4 C$ di sekolah dasar dengan mengintegrasikan pembelajaran IPA, Matematika dan Bahasa Indonesia. Desain pembelajaran STEM disusun berdasarkan 5 tahapan dalam langkahlangkah mengajar diantaranya menanya, membayangkan, merencanakan, membuat dan meningkatkan. Tahapan tersebut melibatkan keterampilan collaboration, critical thinking, creativity dan communication.
\end{abstract}

Kata kunci: Desain Pembelajaran, STEM, FGD

\section{STEM LEARNING DESIGN BASED ON CAPABILITY 4C IN ELEMENTARY SCHOOL}

\begin{abstract}
Learning innovations carried out in elementary schools are still not optimal. This is done because learning in elementary schools generally still uses conventional learning. STEM learning is designed as an alternative innovation based on a thematic curriculum. The STEM learning design was developed in the form of a Learning Implementation Plan (RPP) for Class VI Elementary Schools by applying $4 C$ skills. To obtain the RPP, a qualitative research approach was conducted using the Focus Group Discussion (FGD) method. Data obtained through interviews, observations, documentation studies, FGD processes. Interviews, observations and documentation are conducted to obtain preliminary information about learning designs that are often used by teachers in elementary schools. Whereas the FGD was conducted through group discussions with the aim of validating the development of STEM learning tools. The results obtained in the form of STEM learning design based on the ability of $4 C$ in elementary schools by integrating learning science, mathematics and Indonesian. The STEM learning design is based on 5 stages in the steps of teaching including asking, imagining, planning, making and improving. These stages involve collaboration skills, critical thinking, creativity and communication.
\end{abstract}

Keywords: Learning Design, STEM, FGD 


\section{PENDAHULUAN}

Pembelajaran dilakukan dengan melibatkan guru, siswa, dan sumber belajar lainnya yang dapat meningkatan terjadinya suatu interaksi untuk mencapai tujuan yang telah ditetapkan. Interaksi tersebut merupakan suatu usaha yang sengaja dilakukan dengan melibatkan dan menggunakan pengetahuan profesional yang dimiliki guru untuk menjadikan siswa mencapai tujuan kurikulum (Kosasih, 2018: 11). Suatu rencana atau langkah-langkah harus dipersiapkan guru ketika akan melakukan proses pembelajaran agar belangsung secara efektif (Gofur, 2012: 20). Rancangan Pembelajaran tidak dilakukan hanya berpusat pada peran guru, melainkan lebih kepada peran siswa yang harus terlibat aktif dalam pembelajaran. Standar baru diperlukan agar siswa kelak memiliki kompetensi yang diperlukan pada abad ke-21. Sekolah ditantang menemukan cara dalam rangka memungkinkan siswa sukses dalam pekerjaan dan kehidupan melalui penguasaan keterampilan berfikir kreatif, pemecah masalah yang fleksibel, berkolaborasi dan berinovasi (Zubaidah, 2016). Pembelajaran abad 21 memiliki karakteristik bahwa setiap siswa diarahkan untuk memiliki keterampilan $4 C$ (Putra \& Nurlizawati, 2019). Keterampilan tersebut diharapkan dapat meningkatkan mutu pendidikan di Indonesia.

Mutu pendidikan yang baik tentunya harus didukung oleh faktor intern maupun ekstern. Salah satu upaya yang dapat dilakukan untuk meningkatkan mutu pendidikan adalah proses pembelajaran yang dilakukan oleh guru (Widoyoko, 2008). Pembelajaran yang baik tentunya harus dipersiapkan dengan matang sebelum dilakukannya proses pembelajaran. Untuk itu guru perlu menyiapkan desain pembelajaran yang kreatif, inovatif, dan bermakna sehingga tujuan pembelajaran yang sudah dirancang akan tercapai. Pembelajaran STEM (Science, Technology, Engineering, and Mathematics) merupakan salah satu bentuk pembelajaran yang inovatif serta menuntut proses kreatif dan bermakna. Kebermaknaan dalam pembelajaran ini adalah adanya proses engieering (Torlakson, 2014). Adanya proses engineering ini, siswa tidak hanya memahami pengetahuan saja tetapi adanya keterampilan yang harus dipahami siswa dalam mendapatkan suatu konsep, sehingga pembelajaran yang didapat akan lebih bermakna. Pembelajaran STEM dapat efektif diterapkan pada pembelajaran tematik integratif karena menggabungkan empat bidang disiplin ilmu yaitu sains, technology, engineering, and mathematics (Sukmana, 2017:194).

Pembelajaran STEM juga berupaya memunculkan keterampilan dalam diri siswa untuk merekayasa, misalnya dalam menyelesaikan persoalan dan melakukan penyelidikan (Khoiriyah, et al., 2018:60). Serta dapat mendorong siswa untuk menciptakan suatu hal yang baru dari hasil merekayasa. Proses dalam merekayasa pada pembelajaran STEM erat kaitannya dengan kemampuan abad 21. Proses pembelajaran STEM ini dapat dilakukan dengan mengintegrasikan keterampilan berfikir kritis, berkolaborasi, berfikir kreatif, dan cakap berkomunikasi atau lebih dikenal dengan $4 C$. 
Keterampilan $4 C$ disebut sebagai keterampilan "The $4 C s$ " yaitu keterampilan yang meliputi berfikir kritis, kreatif, komunikasi, dan kolaborasi (Nasional Education Association, 2010:5). Melalui keterampilan-keterampilan ini, sangat diharapkan kompetensi SDM di Indonesia akan meningkat menjadi lebih baik.

Pembelajaran STEM beberapa tahun terakhir ini telah banyak diterapkan beberapa negara seperti Taiwan (Khoiriyah et al., 2018:54), kemudian menjadi primadona di negara maju seperti Amerika Serikat, Finlandia, Jepang, Australia, Tiongkok yang notabennya mendidik siswa menjadi produktif (Musnidar, 2018:176). Namun di Indonesia sendiri pembelajaran STEM masih kurang dikenali oleh guru (Bunyamin, 2016), khususnya guru di Sekolah Dasar (SD). Pembelajaran STEM di Indonesia belum diintegrasikan dalam kurikulum pembelajaran di SD, dimana guru masih menerapkan pembelajaran terintegrasi tematik model dan pendekatan ilmiah sebagai pendekatan utama dalam kurikulum di SD. Hal tersebut terjadi karena berkaitan dengan (1) kompetensi guru diantaranya belum terfasilitasinya ilmu pengetahuan mengenai STEM, (2) Manajemen sekolah yang belum maksimal dalam memfasilitasi kegiatan khususnya untuk kegiatan praktikum, serta (3) Kurikukum SD yang belum terintegrasi antar pembelajaran matematika dengan IPA, karena pembelajaran matematika sendiri di SD kebijakannya tidak diintegrasikan dengan pembelajaran lain (Lidinillah, et. al, 2019:5). Pembelajaran STEM ini sangat cocok untuk diterapkan di dalam kurikulum SD saat ini karena sesuai dengan pembelajaran pada kurikulum 2013 melalui integrasi beberapa mata pelajaran dalam satu pembelajaran, dan diaplikasikan dalam konteks dunia nyata (Nurlenasari, Lidinillah, Nugraha, \& Hamdu, 2019:1).

Hasil penelitian Hamdu, et. al, (2016) mengatakan bahwa kurangnya beberapa sumber tentang teori, penyusunan, contoh tentang perangkat pembelajaran, dan pemahaman guru mengenai cara membuat perangkat pembelajaran masih dirasa kurang. dari hasil penelitian yang dilakukan oleh Gustina (2018) menyatakan bahwa pada faktanya pengembangan desain pembelajaran belum dilakukan secara optimal. Para guru masih menggunakan tahapan pembelajaran berdasarkan pada buku tematik guru tanpa dimodifikasi sesuai dengan keadaan dan karakteristik siswa sebenarnya. Gustiana pun melakukan analisis terhadap RPP (Rencana Pelaksanaan Pembelajaran) yang dibuat oleh beberapa sekolah di Tasikmalaya dan terbukti bahwa banyak guru yang melakukan proses pembelajaran dengan metode konvensional.

Untuk meningkatkan praktik pendidikan maka dalam artikel Giamellaro dan Siegel (2018) melakukan penelitian dengan judul "Coaching teacher to implement innovations in STEM". Hal tersebut dilakukan karena mutu pendidikan sangat penting untuk di tingkatkan dan STEM merupakan suatu disiplin dan praktik pendidikan yang sangat menantang dan berpengaruh bagi masa depan. Maka dari itu, dalam penelitiannya guru sebagai pendidik sangat membutuhkan dukungan untuk melakukan 
pelatihan dalam pengimplementasian STEM dalam pembelajaran (Giamellaro \& Siegel, 2018:36).

Berdasarkan studi literatur yang dilakukan, telah mendorong peneliti untuk merancang RPP STEM guna memperbaiki proses pembelajaran yang sesuai dengan kurikulum 2013, diantaranya pembelajaran berpusat pada siswa, adanya pengintegrasian beberapa mata pelajaran (S-T-E-M). Selain itu, tidak hanya pengetahuan yang dikembangkan namun diimplementasikan melalui keterampilan engineering, dan dalam proses pembelajaran STEM dapat menjadikan siswa berfikir kritis, mampu memecahkan masalah, kreatif, mampu bekerjasama, dan pandai berkomunikasi. Penelitian ini menjadi penting dilakukan untuk memfasilitasi guru dalam memperoleh informasi mengenai desain pembelajaran yang inovatif, kreatif dan bermakna berkaitan dengan pembelajaran STEM, dan dapat memotivasi guru untuk membuat desain pembelajaran STEM pada materi lain.

\section{METODE PENELITIAN}

Pendekatan qualitative reseach dengan metode Focus Group Discussion (FGD) digunakan dalam penelitian ini. Metode $F G D$ adalah salah satu metode penelitian kualitatif yang paling populer (Omar, 2018:2). FGD dapat didefinisikan sebagai metode dan teknik untuk mengumpulkan data kualitatif dengan sekelompok orang untuk berdiskusi berkaitan suatu fokus masalah atau topik tertentu dipandu oleh seseorang moderator atau fasilitator (Indrizal, 2014:76). Untuk memperoleh produk data/informasi dari FGD tersebut dilakukan melalui interaksi sosial sekelompok individu yang saling mempengaruhi satu sama lain (Omar, 2018).

Berdasarkan permasalahan yang terjadi, peneliti ingin memberikan solusi berupa pengembangan desain pembelajaran STEM dalam bentuk RPP. Desain pembelajaran tersebut dikembangkan berdasarkan penelitian yang telah dilakukan dengan mengacu pada studi literatur, studi pendahuluan di lapangan terkait penggunaan RPP, dan juga proses FGD mengenai rancangan RPP yang dibuat dengan model STEM. Tahapan proses yang dilakukan dengan mengacu pada langkah-langkah dengan metode $F G D$ menurut Glynn, et al, (2015), yaitu: 


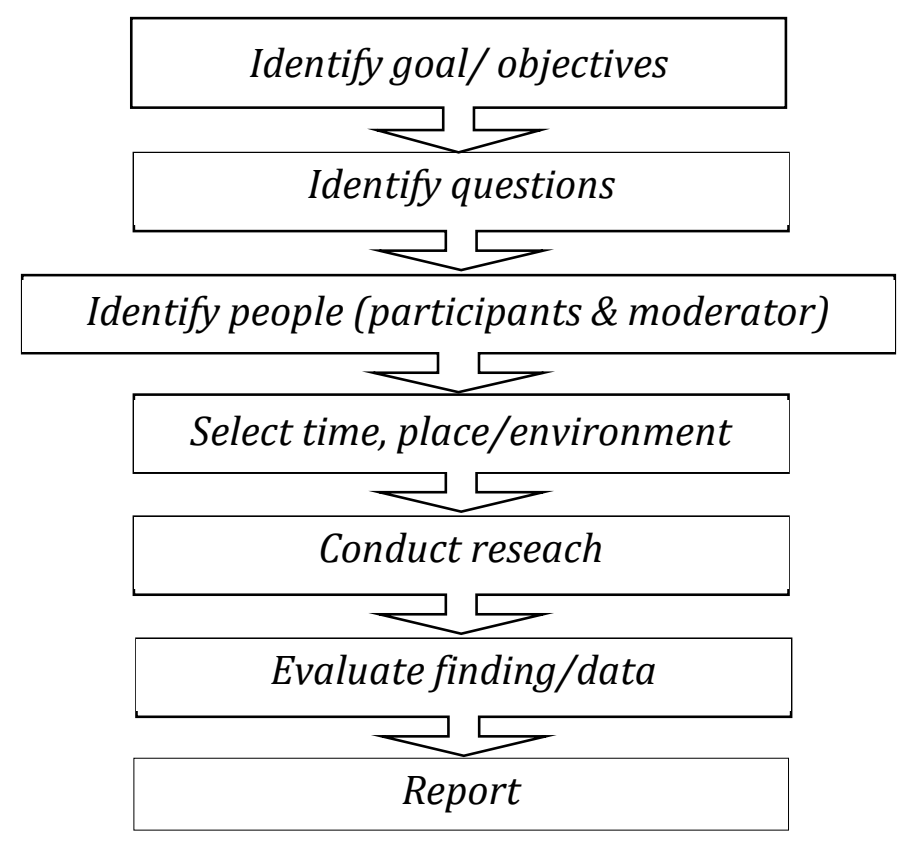

Gambar 1. Tahapan Proses FGD

(Glynn, Shanahan and Duggan, 2015)

Tahapan tersebut didahului dengan melakukan identifikasi tujuan atau objek penelitian yang diperkuat dengan melakukan studi literatur dan studi pendahuluan ke SD di Tasikmalaya. Setelah adanya tujuan dan solusi yang didapat dari studi lapangan, dilanjutkan dengan menyusun desain pembelajaran STEM dalam bentuk RPP. Desain pembelajaran yang dibuat kemudian divaliadasi dengan melakukan proses FGD dengan tujuan untuk menghasilkan rancangan yang sesuai dengan pembelajaran STEM. Namun sebelum dilakukan $F G D$, proses identifikasi dengan menyusun pertanyaan untuk kegiatan $F G D$, mengidentifikasi partisipan yang terlibat selama melakukan FGD terhadap desain pembelajaran STEM, serta memilih waktu dan tempat kegiatan FGD. RPP yang telah divalidasi melalui proses $F G D$ kemudian dievaluasi dengan melibatkan expert untuk dinilai apakah rancangan ini telah layak atau tidak menurut kaidah pembelajaran STEM dan kecocokan untuk diimplementasikan di tingkat SD.

Pengumpulan data dalam penelitian ini dilakukan dengan teknik wawancara, observasi, studi dokumentasi, dan FGD. Partisipan yang terlibat dalam wawancara mengenai desain pembelajaran yang sering digunakan di sekolah adalah guru SD kelas VI di SDN 3 Manonjaya dan SDN Mancogeh, Tasikmalaya. Sedangkan partisipan dalam melakukan $F G D$ dipilih berdasarkan ciri yang sama yaitu anggota tim lain yang khusus dalam mengembangkan perangkat pembelajaran STEM sejumlah 7 orang dengan berkonsentrasi masing-masing kepada pengembangan rencana pelaksanaan 
pembelajaran (RPP), media, Lembar kerja Siswa (LKS), bahan ajar, penilaian tes tertulis, asesmen kinerja dan pengembangan video pelaksanaan pembelajaran.

\section{HASIL DAN PEMBAHASAN}

\section{Hasil Penelitian}

\section{Identifikasi tujuan atau objek penelitian}

Berdasarkan tujuan penelitian, peneliti bermaksud untuk mengembangkan desain pembelajaran dalam bentuk RPP, karena untuk menghasilkan proses pembelajaran yang baik tentunya harus dirancang terlebih dahulu desain pembelajaran yang akan dilakukan. Fokus tujuan pengembangan kepada desain pembelajaran STEM berdasarkan kemampuan $4 C$ dalam bentuk RPP untuk kelas VI di Sekolah Dasar.

Untuk mengetahui bagaimana desain pembelajaran yang biasa digunakan oleh guru di SDN 3 Manonjaya dan SDN Mancogeh di Tasikmalaya, peneliti melakukan wawancara langsung sebagai studi pendahuluan untuk mendapatkan informasi mengenai RPP yang dibuat guru. Hasil wawancara diperoleh bahwa pembelajaran yang dilakukan sudah menerapkan kurikulum 2013. Namun ketika dipertanyakan terkait desain pembelajaran yang dilakukan belum menginovasi pembelajaran kurikulum 2013 secara meluas. Artinya narasumber masih menggunakan desain pembelajaran berdasarkan urutan pada buku guru tanpa adanya modifikasi dan pengembangan, selain itu juga mengungkapkan bahwa jarangnya guru dalam membuat RPP. Sedangkan narasumber dari SDN Mancogeh mengatakan bahwa "ketika guru mendesain pembelajaran dengan inovasi yang sangat ideal itu belum tentu akan tercapai dengan hasil yang ideal, maka guru harus mengetahui karakteristik siswa terlebih dahulu, bisa jadi siswa itu tidak bisa menerima desain yang telah dirancang dengan baik sehingga bisa jadi boomerang yang tidak baik bagi mereka dalam memahami materi tersebut". Kemudian ketika membahas mengenai pembelajaran IPA khususnya yang membutuhkan siswa untuk melakukan keterampilan proses dilakukan dengan menyesuaikan pembelajaran dengan apa yang ada di buku siswa, begitupun dengan praktikum disesuaikan dengan yang ada pada buku. Padahal jika diberikan inovasi maka hasil produk yang digunakan akan bernilai tinggi esensinya bagi diri siswa.

Berdasarkan studi pendahuluan dan mengobservasi RPP yang dibuat guru di sekolah menjadi dasar bagi peneliti untuk mengembangkan pembelajaran yang lebih inovatif, kreatif dan bermakna bagi siswa. Salah satunya pembelajaran STEM berdasarkan kemampuan $4 C$ yang sebelumnya belum diterapkan di sekolah. RPP pembelajaran STEM ini dirancang untuk mengarahkan siswa dapat melakukan rekayasa terhadap materi yang dipelajari dengan membuat suatu produk. Pengalaman tersebut diharapkan dapat menjadikan pengalaman dan bekal kehidupan siswa dalam karirnya di masa depan. Lingkup RPP STEM yang dikembangkan peneliti untuk digunakan di kelas VI SD. 
FGD awal dilakukan dengan melakukan persamaan persepsi bersama tim pengembang perangkat pembelajaran lainnya yang berkaitan dengan hasil studi pendahuluan, pembelajaran STEM yang akan dilakukan, orientasi pemilihan kompetensi yang akan dikembangkan sebagai pembelajaran STEM dan pengembangan media yang akan membantu proses pembelajaran STEM. Setelah itu, dilanjutkan dengan menyusun rancangan RPP awal. Setelah rancangan RPP awal dibuat peneliti, dilakukan kembali proses $F G D$ untuk mendapatkan informasi mendalam mengenai keefektifan desain pembelajaran STEM yang telah dibuat. Sehingga dengan adanya proses FGD dapat dijadikan sebagai dasar validasi produk RPP STEM yang layak digunakan guru dalam pembelajaran di SD. Proses FGD ini sebelumnya didahului dengan identifikasi terhadap pertanyaan yang diajukan pada proses $F G D$ serta memilih partisipan, waktu dan tempat untuk kegiatan FGD.

\section{Identifikasi pertanyaan-pertanyaan atau permasalahan tentang objek penelitian}

Pertanyaan dalam FGD digunakan pertanyaan terbuka (open ended) sehingga memungkinkan peserta FGD memberikan jawaban disertai dengan penjelasan (Paramita, 2013:119). Pertanyaan disusun dari pertanyaan sederhana ke pertanyaan kompleks mengenai produk RPP STEM yang dibuat. Namun dalam pelaksanaanya, pertanyaan yang disusun dapat dikembangkan sesuai dengan respon dari peserta. Pertanyaan tersebut secara garis besar diantaranya:

a. Bagaimana Kompetensi Dasar yang digunakan apakah sudah mengintegrasikan pembelajaran STEM?

b. Apakah Kata Kerja Operasional dalam IPK sudah menunjukan sikap, pengetahuan, dan keterampilan?

c. Apakah langkah kegiatan 1-5 sudah menunjukkan kegiatan STEM?

d. Apakah langkah pembelajaran STEM ini sudah mengintegrasikan keterampilan $4 C$ dalam kegiatan siswa?

\section{Mengidentifikasi partisipan penelitian}

Setelah menyusun pertanyaan, selanjutnya menentukan kelompok diskusi terarah atau FGD. Dalam menentukan partisipan dilakukan berdasarkan kriteria pelaksanaan $F G D$ yaitu peserta $F G D$ idealnya diikuti sebanyak 7-11 orang. Hal tersebut dilakukan untuk memungkinkan setiap orang mengeluarkan pendapat. Kemudian peserta $F G D$ terdiri dari orang-orang yang memiliki ciri yang relatif sama (Indrizal, 2014:76). Dalam implementasi pengembangan desain pembelajaran ini, dilibatkan sebanyak 7 orang partisipan mahasiswa PGSD (Pendidikan Guru Sekolah Dasar) yang tergabung dalam payung penelitian pengembangan pembelajaran berbasis STEM di sekolah dasar. Peran dari partisipan tersebut, yaitu: 
Partisipan $1 \quad$ : Peserta yang berkontribusi mengembangkan desain pembelajaran STEM dalam bentuk rencana pelaksanaan pembelajaran.

Partisipan 2 : Peserta yang berkontribusi mengembangkan media pembelajaran STEM.

Partisipan 3 : Peserta yang berkontribusi mengembangkan Lembar Kerja Siswa berbasis STEM.

Partisipan $4 \quad$ : Peserta yang berkontribusi mengembangkan modul pembelajaran STEM.

Partisipan 5 : Peserta yang berkontribusi mengembangkan penilaian tertulis berbasis STEM.

Partisipan 6 : Peserta yang berkontribusi mengembangkan asesmen kinerja berbasis STEM.

Partisipan $7 \quad$ : Peserta yang berkontribusi mengembangkan video pembelajaran STEM.

Penelitian ini dilakukan secara kolaboratif sehingga menghasilkan produk perangkat pembelajaran STEM. Selain itu ditentukan pula diskusi dengan melibatkan fasilitator ahli pembelajaran STEM. Dalam artikel ini, posisi penulis khusus membahas berkaitan dengan pengembangan desain pembelajaran STEM dalam bentuk rencana pelaksanaan pembelajaran.

\section{Memilih waktu dan tempat proses FGD}

Diskusi terarah dalam menentukan rancangan produk RPP STEM dilaksanakan sebanyak 3 kali pertemuan. Waktu yang dibutuhkan yaitu 90 menit dalam setiap pertemuan. Tempat pelaksanaan FGD awal dilakukan di Laboratorium IPA tepatnya di UPI Kampus Tasikmalaya dan FGD selanjutnya dilakukan melalui media virtual zoom. Dalam menentukan waktu serta tempat disesuaikan dengan kriteria $F G D$ yaitu antara 60-90 menit (Indrizal, 2014:77). Hal ini dikarenakan jika waktu diskusi terlalu pendek dikhawatirkan informasi yang didapat sangat terbatas, sedangkan jika waktu yang digunakan terlalu panjang maka akan berpengaruh terhadap konsentrasi peserta. Sedangkan untuk tempat penelitian disesuaikan dengan kondisi dan tempat yang dapat membuat peserta nyaman dan bebas untuk mengeluarkan pendapat.

\section{Melakukan kegiatan penelitian dengan FGD}

Hasil FGD yang dilakukan bersama tim mengenai rancangan desain pembelajaran yang dibuat peneliti yaitu dengan menganalisis Kompetensi Dasar (KD) berdasarkan kurikulum 2013. Dalam produk RPP ini, peneliti tidak terlepas dari peran tim pengembang perangkat pembelajaran lain, sebab implementasi RPP ini tidak dapat berdiri sendiri sehingga antara satu komponen perangkat pembelajaran satu dengan yang lainnya saling berkaitan. Penentuan KD dibutuhkan dan disesuaikan dengan 
kebutuhan dan penyamaan persepsi dari seluruh tim pengembang perangkat pembelajaran STEM.

Tabel 1. Analisis Awal kurikulum pembelajaran STEM

\begin{tabular}{|c|c|c|c|c|}
\hline Kelas & Sains & Teknologi & Engineering & Matematika \\
\hline $\mathrm{V}$ & $\begin{array}{l}\text { Alat gerak dan } \\
\text { fungsinya pada } \\
\text { hewan }\end{array}$ & Burung terbang & $\begin{array}{l}\text { Langkah-langkah } \\
\text { membuat burung } \\
\text { terbang }\end{array}$ & Kecepatan \\
\hline $\mathrm{V}$ & $\begin{array}{l}\text { Alat gerak dan } \\
\text { fungsinya pada } \\
\text { manusia }\end{array}$ & Wayang orang & $\begin{array}{l}\text { Langkah-langkah } \\
\text { membuat } \\
\text { wayang orang }\end{array}$ & $\begin{array}{l}\text { Menjelaskan dan } \\
\text { menentukan } \\
\text { ukuran sudut. }\end{array}$ \\
\hline VI & $\begin{array}{l}\text { Komponen } \\
\text { listrik } \\
\text { sederhana }\end{array}$ & $\begin{array}{l}\text { Mobil Electrical } \\
\text { Tandem } \\
\text { Roller(ETR) }\end{array}$ & $\begin{array}{l}\text { Langkah-langkah } \\
\text { membuat mobil } \\
\text { ETR }\end{array}$ & Kecepatan. \\
\hline
\end{tabular}

Dari hasil analisis yang dilakukan pada tabel 1, hasil FGD yang dilakukan berdasarkan beberapa pendapat dan argumen yang saling menguatkan, dipilihlah analisis pada pilihan ke tiga yaitu komponen listrik sederhana di kelas VI diintegrasikan dengan materi matematika di kelas V mengenai kecepatan, sehingga akan menghasilkan teknik dalam membuat teknologi berupa mobil Tandem Roller (setum). Berdasarkan hasil diskusi, hal tersebut dilakukan karena pada tahap rekayasa menekankan pada pembelajaran dan hasil teknologi berbasis STEM. Dari analisis kurikulum ditentukanlah Kompetensi Dasar yang akan dicantumkan dalam RPP STEM berdasarkan hasil penetapan $F G D$, sebagai berikut:

Tabel 2. Kompetensi Dasar

\begin{tabular}{|c|c|c|}
\hline No & Mata Pelajaran & Kompetensi Dasar (KD) \\
\hline 1 & IPA & $\begin{array}{l}\text { 1.4 Mengidentifikasi komponen-komponen listrik dan } \\
\text { fungsinya dalam rangkaian listrik sederhana. } \\
\text { 4.4 Melakukan percobaan rangkaian listrik sederhana secara }\end{array}$ \\
\hline 2 & Matematika & $\begin{array}{l}\text { 3.3 Menjelaskan perbandingan dua besaran yang berbeda } \\
\text { (kecepatan sebagai perbandingan jarak dengan waktu, } \\
\text { debit sebagai perbandingan) } \\
\text { 4.3 Menyelesaikan masalah yang berkaitan dengan } \\
\text { perbandingan dua besaran yang berbeda (kecepatan, } \\
\text { debit). }\end{array}$ \\
\hline 3 & $\begin{array}{l}\text { Bahasa } \\
\text { Indonesia }\end{array}$ & $\begin{array}{l}\text { 3.2 Menggali isi teks penjelasan (eksplanasi) ilmiah yang di } \\
\text { dengar dan di baca. } \\
\text { 4.2 Penyajian hasil penggalian informasi dan teks penjelasan } \\
\text { (eksplanasi) ilmiah secara lisan, tulis, dan visual dengan } \\
\text { menggunakan kosakata baku dan kalimat efektif. }\end{array}$ \\
\hline
\end{tabular}

Setelah menetukan KD, langkah selanjutnya yaitu menjabarkan KD ke dalam indikator pencapaian kompetensi. Moderator melakukan tanya jawab kepada peserta terkait pemilihan Kata Kerja Operasional (KKO) yang tepat dan sesuai dengan pembelajaran STEM. Hasil FGD yang dilakukan mengenai Indikator Pencapaian Kompetensi (IPK) secara garis besar harus dapat membuat siswa berfikir kritis terhadap 
suatu masalah, dan dapat memenuhi kriteria keterampilan $4 C$. Tabel 3 merupakan hasil yang disepakati oleh peserta dan fasilitator pembelajaran STEM terkait IPK yang dicantumkan dalam RPP.

Tabel 3. Indikator Pencapaian Kompetensi

\begin{tabular}{ccl}
\hline \multicolumn{1}{c}{ Mata Pelajaran } & \multicolumn{1}{c}{ Indikator Pencapaian Kompetensi } \\
\hline IPA & 1.4 .1 & $\begin{array}{l}\text { Menelaah beberapa komponen listrik dalam rangkaian } \\
\text { listrik sederhana. }\end{array}$ \\
& 1.4 .2 & $\begin{array}{l}\text { Menelaah fungsi beberapa komponen listrik dalam } \\
\text { rangkaian listrik sederhana. } \\
\text { Membuat rancangan rangakaian listrik sederhana secara } \\
\text { seri dan paralel. }\end{array}$ \\
& 4.4 .1 & $\begin{array}{l}\text { Membuat rangkaian listrik sederhana secara seri atau } \\
\text { paralel pada media ETR. }\end{array}$ \\
Matematika & 4.4 .3 & $\begin{array}{l}\text { Membuat rangkaian listrik campuran pada media ETR. } \\
\text { Benjelaskan perbandingan jarak dengan waktu. }\end{array}$ \\
& 3.3 .1 & $\begin{array}{l}\text { Menyelesaikan masalah yang berkaitan dengan } \\
\text { kecepatan media ETR }\end{array}$ \\
& 3.2 .1 & $\begin{array}{l}\text { Menggali beberapa informasi penting dari teks } \\
\text { eksplanasi yang di baca. } \\
\text { Menyajikan beberapa informasi penting dari teks } \\
\text { eksplanasi secara tertulis dengan menggunakan } \\
\text { kosakata baku dan efektif. }\end{array}$ \\
\hline
\end{tabular}

Penyusunan tujuan pembelajaran disesuaikan dengan KD dan IPK yang telah dirumuskan. Karena tujuan pembelajaran menggambarkan proses dan hasil pembelajaran yang diharapkan. Perumusan tujuan pembelajaran yang baik dinyatakan dalam bentuk $A B C D$, yang artinya: A (Audience), yaitu sebagai subjek seperti siswa, mahasiswa, dan lain-lain; B (Behavior), yaitu perilaku teramati sebagai hasil belajar; C (Condition), yaitu pencapaian perilaku yang diharapkan sesuai dengan syarat kondisi tertentu; D (Degree), yaitu tingkat tampilan perilaku yang dapat diterima (Uno, 2006).

FGD dilanjutkan dengan membahas kegiatan langkah-langkah pembelajaran STEM yang telah disusun oleh peneliti. Adapun hasil FGD dalam bentuk tabel agar terlihat lebih jelas perubahan kegiatan langkah-langkah pembelajaran sebagai berikut:

Tabel 4. Hasil FGD mengenai perubahan Kegiatan langkah-langkah pembelajaran STEM

\begin{tabular}{|c|c|c|c|}
\hline $\begin{array}{c}\text { Tahapan } \\
\text { STEM }\end{array}$ & Desain awal peneliti & Revisi hasil FGD & Revisi hasil akhir \\
\hline $\begin{array}{l}\text { Tahap } 1 \\
\text { Menanya }\end{array}$ & 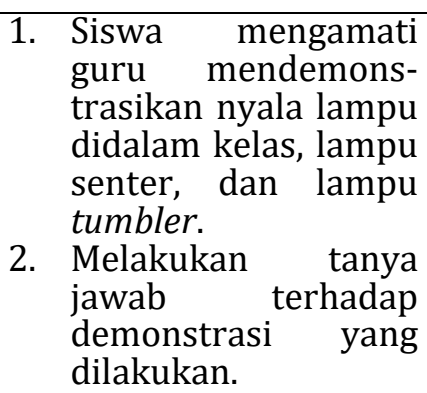 & $\begin{array}{l}\text { Dilakukan perbaikan menjadi: } \\
\text { 1. Siswa mengamati gambar } \\
\text { yang ditampilkan guru } \\
\text { (mengenai jalanan yang } \\
\text { rusak), kemudian } \\
\text { memberikan tanggapan } \\
\text { terhadap gambar di LKS. } \\
\text { 2. Siswa mengamati video } \\
\text { pembelajaran (mengenai } \\
\text { jalanan yang rusak sedang }\end{array}$ & $\begin{array}{l}\text { Setelah memberikan } \\
\text { tanggapan terhadap } \\
\text { gambar dan video, } \\
\text { dilakukan langkah } \\
\text { berikut: } \\
\text { 1. Siswa } \\
\text { memperdalam } \\
\text { pengetahuan } \\
\text { mengenai tandem } \\
\text { dengan membaca }\end{array}$ \\
\hline
\end{tabular}




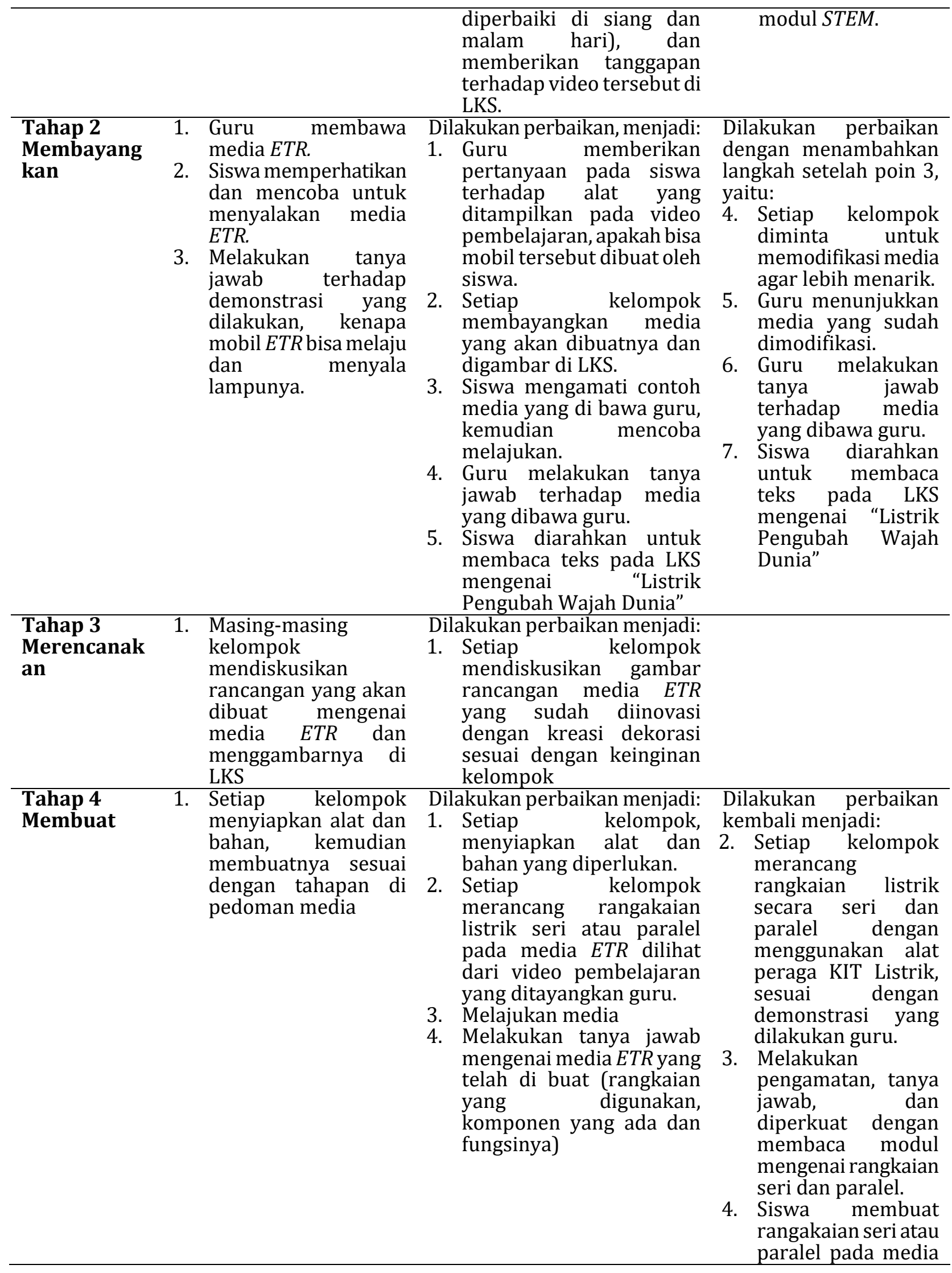




\begin{tabular}{|c|c|c|c|}
\hline & & & $\begin{array}{l}\text { ETR berdasarkan } \\
\text { petunjuk di LKS. } \\
\text { 5. Siswa menghias } \\
\text { produk. } \\
\text { Dilanjutkan dengan } \\
\text { langkah perbaikan } \\
\text { terakhir yang di tambah } \\
\text { setelah poin 5, yaitu: } \\
\text { 6. Media yang sudah } \\
\text { dihias, diuji cobakan } \\
\text { dalam lomba } \\
\text { parade. } \\
\text { Setiap kelompok } \\
\text { menghitung media } \\
\text { kecepatan man } \\
\text { ETR dara } \\
\text { menjelaskan bagai } \\
\text { mana cara } \\
\text { menghitungnya. }\end{array}$ \\
\hline $\begin{array}{l}\text { Tahap } 5 \\
\text { Meningkat- } \\
\text { kan }\end{array}$ & $\begin{array}{l}\text { 1. } \text { Membuat } \\
\text { peningkatan dengan } \\
\text { merangkai secara } \\
\text { campuran } \\
\text { 2. Hasil karya yang di } \\
\text { buat, dilombakan } \\
\text { dengan media ETR } \\
\text { kelompok lain. } \\
\text { Kemudian } \\
\text { menghitung } \\
\text { kecepatan } \\
\text { diperoleh yang } \\
\text { masing-masing media } \\
\text { yang diletakan di titik } \\
\text { start, untuk dihitung } \\
\text { berapa lama waktu } \\
\text { yang dibutuhkan } \\
\text { setiap media untuk } \\
\text { sampai di titik finish }\end{array}$ & $\begin{array}{l}\text { Dilakukan perbaikan yaitu: } \\
\text { Langkah no } 2 \text {, dipindahkan ke } \\
\text { tahap } 4 \text { revisi akhir setelah } \\
\text { langkah } 5 \text {. Kemudian langkah } \\
\text { no } 4 \text { revisi ke-1 dipindahkan } \\
\text { ke tahap } 5 \text { setelah membuat } \\
\text { rangkaian campuran pada } \\
\text { media ETR }\end{array}$ & $\begin{array}{l}\text { Perbaikan terakhir } \\
\text { menjadi: } \\
\text { 1. Membuat } \\
\text { peningkatan dengan } \\
\text { merangkai secara } \\
\text { campuran pada KIT } \\
\text { listrik dan media } \\
\text { ETR } \\
\text { 2. Setiap kelompok } \\
\text { melajukan kembali } \\
\text { media yang telah } \\
\text { ditingkatkan } \\
\text { Setiap kelompok } \\
\text { mengamati } \\
\text { komponen apa yang } \\
\text { harus ada dalam } \\
\text { membuatrangkaian } \\
\text { media ETR agar bisa } \\
\text { melaju dan } \\
\text { menghasilkan nyala } \\
\text { lampu }\end{array}$ \\
\hline
\end{tabular}

\section{Mengevaluasi data yang ditemukan}

Tahap ini dilakukan untuk mempertimbangkan hasil FGD yang telah dilakukan dengan beberapa argumen yang diberikan serta validasi ahli STEM. Adapun contoh hasil desain pembelajaran dirancang dalam bentuk kegiatan langkah-langkah pembelajaran dalam RPP dapat dilihat sebagai berikut:

Tabel 5. Langkah Kegiatan Pembelajaran (kegiatan Inti)

\begin{tabular}{lll}
\hline Tahap 1 & Menanya (mendefinisikan masalah dan mengidentifikasi batasan) \\
\hline & 1. & Siswa dibagi menjadi 4 kelompok, kemudian diberikan \\
& mahkota number untuk mempermudah penilaian & \\
individu dan kelompok. & 25 menit \\
2. & $\begin{array}{l}\text { Setiap kelompok mendapatkan LKS, kemudian } \\
\text { menuliskan identitas dan memahami petunjuk yang }\end{array}$ & \\
\hline
\end{tabular}


ada di LKS.

3. Siswa mengamati gambar yang ditampilkan guru mengenai jalanan yang rusak.

4. Siswa diarahkan oleh guru untuk memberikan tanggapan terhadap gambar tersebut dan menuliskan hasil tanggapannya di LKS.

Penilaian Kinerja (Individu) : Critical Thinking (informasi dan penemuan)

5. Untuk mengetahui Tandem, siswa diarahkan guru membaca buku modul (Bagaimana aku bekerja).

6. Siswa diarahkan guru untuk mengamati video yang ditayangkan guru mengenai Tandem.

7. Siswa melalui bimbingan guru melakukan tanya jawab mengenai video yang diamati siswa dan hasilnya ditulis dalam LKS.

Penilaian Kinerja (Individu) : Critical Thinking (informasi dan penemuan)

Tahap 2 Membayangkan (menggali gagasan dan memilih yang terbaik)

8. Siswa dengan arahan guru melakukan tanya jawab "Apakah kita bisa membuat alat seperti itu,?", "Kirakira seperti apa ya bentuknya?", "Dari manakah sumber energi agar alat yang kita buat dapat bergerak atau melaju?"

9. Siswa berdiskusi bersama dengan kelompoknya untuk membayangkan bagaimana media yang akan dibuat dengan menggambarkannya di LKS

Penilaian Kinerja (Individu) : Creative (ide desain)

10. Guru menanyakan hasil diskusi satu persatu kelompoknya.

11. Siswa mengamati contoh media ETR yang ditunjukkan oleh guru. Setelah mengamati, guru melakukan tanya jawab dengan siswa.

"Bisakah media tersebut di modifikasi supaya lebih menarik?"

"Bagaimana cara memodifikasinya?"

12. Siswa dengan bimbingan guru diarahkan untuk bisa memodifikasi tandem tersebut.

13. Guru menunjukkan media ETR yang sudah di modifikasi. Setiap kelompok mencoba melajukannya dan menjawab pertanyaan di LKS

14. Siswa dengan arahan guru diminta untuk membaca teks pada LKS tentang "Listrik pengubah dunia"

15. Siswa memahami dan menyajikan hasil bacaan yang di dapat di LKS.

16. Siswa dan guru melakukan tanya jawab mengenai isi bacaan yang ditemukan.

17. Siswa diminta untuk mencari alat dan bahan yang diperlukan dengan menandainya dalam membuat karya/ Media Electrical Tendem Roller di LKS.

18. Siswa menyimak penjelasan guru tentang aturan dalam membuat Media Electrical Tendem Roller.

Tahap 3 Merencanakan (menggambar diagram dan mengumpulkan bahan)

19. Setiap kelompok mendiskusikan pembuatan media 20 menit yang akan dibuat.

20. Siswa diinstruksikan untuk membuat gambar rancangan media Electrical Tendem Roller dengan 
kreasi dekorasi masing-masing kelompok supaya terlihat berbeda dengan kelompok lain.

Penilaian Kinerja (Individu) : Creativity (ide desain)

21. Guru membimbing siswa dalam proses perencanaan desain Media Electrical Tendem Roller

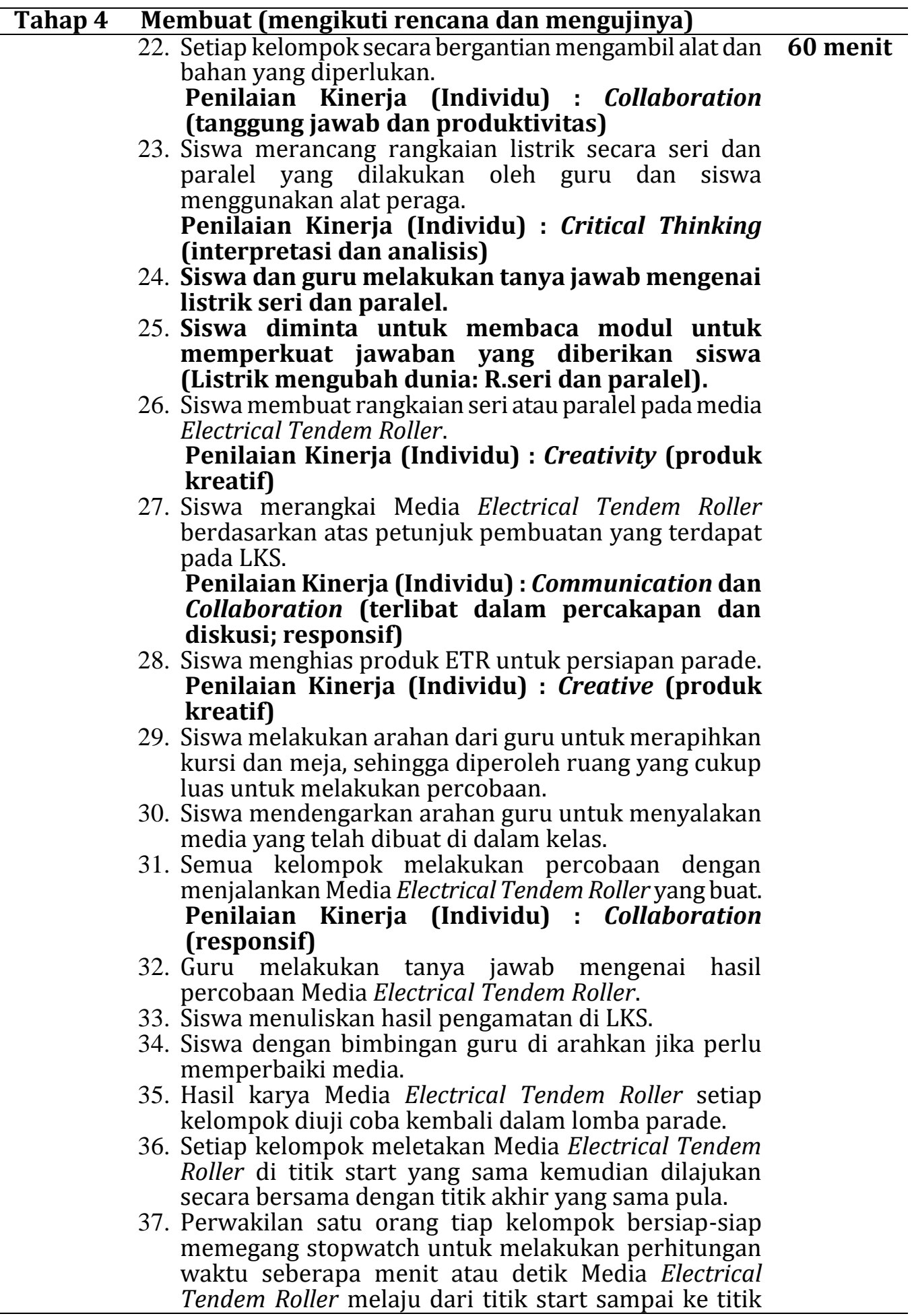




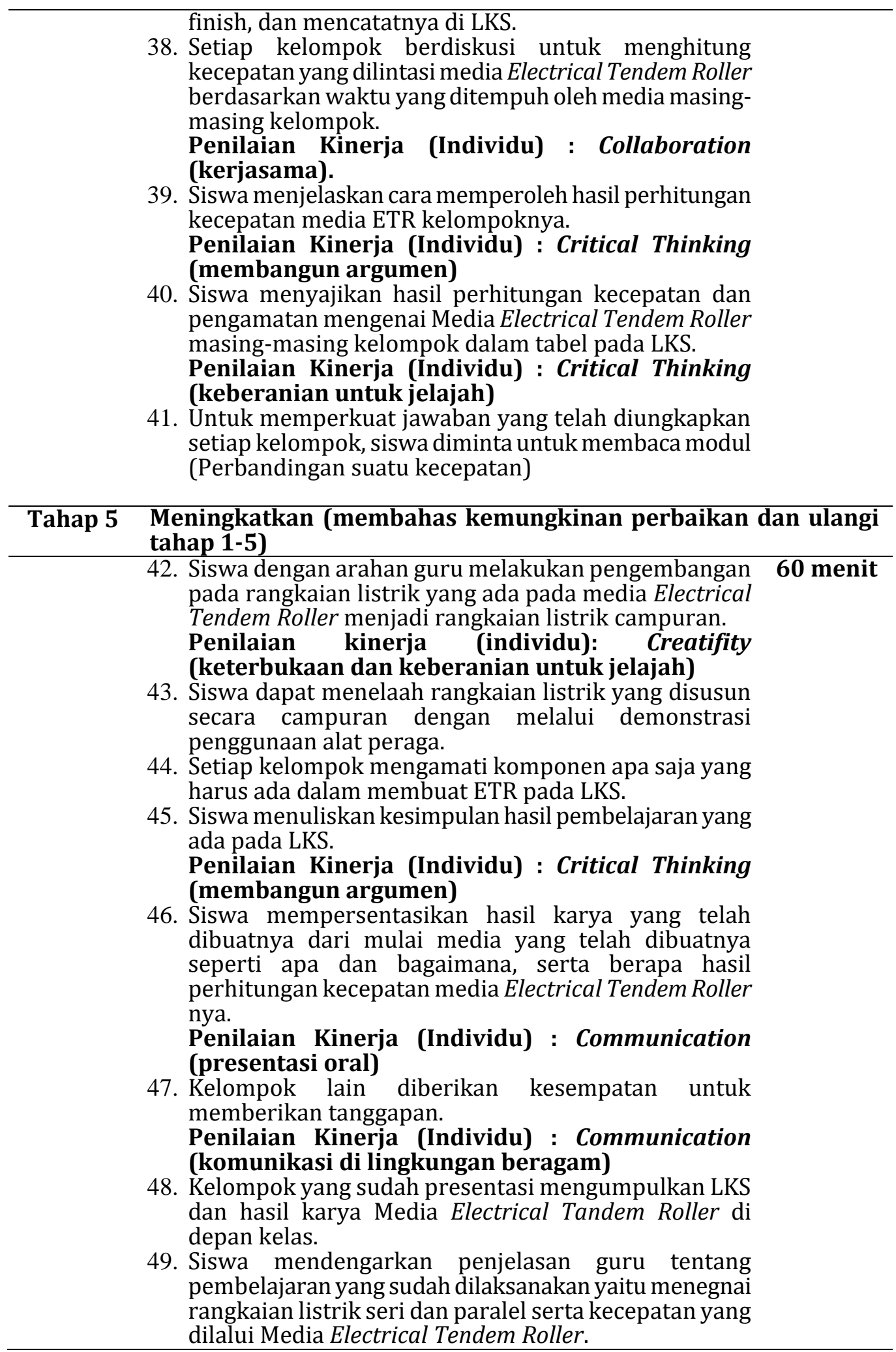

Tabel 5 merupakan contoh langkah kegiatan inti pembelajaran yang tercantum dalam RPP yang disusun peneliti dengan model pembelajaran STEM berdasarkan 
kemampuan 4C. Siswa membuat produk media electrical tandem roller (ETR) sebagai aplikasi dari pembelajaran IPA, Matematika dan Bahasa Indonesia mengenai rangkaian listrik sederhana dan kecepatan terhadap laju mobil tersebut sebagai proses engineering.

\section{Membuat laporan}

Pembuatan laporan dilakukan setelah data dan produk yang dihasilkan telah tervalidasi secara penuh oleh tim $F G D$ sebagai responden dan fasilitator pembelajaran STEM. Penyusunan laporan dilakukan dengan menyusun RPP STEM berdasarkan komponen-komponen RPP yang tertera pada Permendikbud Nomor 22 Tahun 2016. Urutan komponen-komponen tersebut adalah: "(1) identitas sekolah, (2)identitas mata pelajaran/sub tema, (3) penentuan kelas/semester, (4) menentukan alokasi waktu, (5) penulisan $\mathrm{KI} / \mathrm{KD}$, (6) merumuskan indikator pencapaian kompetensi, (7) perumusan tujuan pembelajaran, (8) perumusan materi pembelajaran, (9) penentuan metode pembelajaran, (10) penentuan media/alat, bahan dan sumber belajar, (11) perumusan langkah-langkah pembelajaran, (12) dan pengembangan penilaian pembelajaran."

\section{Pembahasan}

Penelitian ini menghasilkan produk berupa desain pembelajaran berbasis STEM karena berdasarkan masalah yang didapat dilapangan desain pembelajaran yang digunakan guru di SD masih menggunakan model pembelajaran konvensional, yaitu "pembelajaran yang berpusat pada guru, mengutamakan hasil dari pada proses, kemudian metode yang diberikan tidak lepas dari ceramah, pembagian tugas dan latihan sebagai bentuk pendalaman materi ajar", (Ibrahim, 2017:202). Maka dari itu tidak jarang desain pembelajaran yang dirancang pun disesuaikan dengan buku ajar, baik itu buku siswa maupun buku guru tanpa dimodifikasi kembali.

Proses FGD yang dilakukan telah menghasilkan rancangan RPP pembelajaran STEM berdasarkan keterampilan $4 C$. Dalam menggunakan metode FGD dibutuhkan suatu data pendukung lainnya untuk menambah nilai dari hasil kesimpulan FGD (Bisjoe, 2018). Oleh sebab itu dalam konteks pengembangan produk dalam penelitian ini dilakukan dengan secara seksama melalui analisis pendahuluan berupa studi literatur dan studi lapangan. Salah satu kelemahan dalam hasil penelitian ini adalah ruang lingkup produk hasil $F G D$ belum teruji melalui uji lapangan, namun secara konseptual produk RPP ini telah sesuai dengan kaidah dari proses $F G D$, dan kajian-kajian mengenai pengembangan pembelajaran dalam lingkup pembelajaran STEM khususnya di sekolah dasar.

Pembelajaran STEM ini dikembangkan dengan mengacu kepada produk RPP yang mampu mengaplikasikan pembelajaran kurikulum 2013 sesuai dengan abad 21. Permanasari (2016:30) mengatakan bahwa "Pembelajaran berbasis STEM merupakan 
salah satu pembelajaran alternative yang potensial digunakan untuk membangun keterampilan abad 21". Pembelajaran STEM juga dapat dijadikan sebagai praktik dalam mempersiapkan karir di masa depan (Kristien, 2019). Hal tersebut terbukti dari penerapan pembelajaran STEM dapat meningkatkan prestasi siswa yang dibuktikan oleh pelajar di Indonesia sebagai contoh dengan penemuan "Lemari es tanpa listrik" oleh 2 siswa SD kelas VI bernama Arya Nardhana Syariendrar dan Sanika Putra Ramadhan, "Serabut kelapa diubah menjadi rompi anti peluru" oleh 2 siswa SMA Semarang bernama Aristio Kevin Ardyaneira Pratama dan M Iqbal Fauzi, "Lampu seumur hidup" oleh 3 mahasiswa Fakultas Perikanan Dan Ilmu Kelautan Universitas Brawijaya (Musnidar, 2018:176). Oleh sebab itu peneliti memilih penerapan STEM dalam pembelajaran, guna memperbaiki praktik pembelajaran sesuai dengan kondisi saat ini.

Desain pembelajaran yang dirancang dituangkan dalam bentuk Rencana Pelaksanaan Pembelajaran (RPP). RPP dibuat sesuai dengan pedoman penyusunan dalam Permendikbud Nomor 22 Tahun 2016 karena komponennya dirasa lengkap untuk bisa digunakan dalam membuat produk desain pembelajaran STEM yang akan diimplementasikan. RPP disusun berdasarkan Kompetensi Dasar yang termuat dalam kurikulum 2013 setelah dilakukannya analisis kurikulum pembelajaran STEM. Peneliti memilih kelas tinggi dalam penerapan RPP STEM karena disesuaikan dengan kebutuhan materi yang diperlukan untuk melakukan engineering. RPP dengan model STEM memiliki kelebihan yaitu adanyan proses engineering, sehingga siswa dapat mendesain produk sebagai pengaplikasian pengetahuan selama proses pembelajaran. Produk yang dibuat dalam penelitian ini yaitu Electrical Tandem Roller yang dirancang untuk mampu menyususn rangkaian listrik secara seri dan paralel serta kaitannya dengan matematika untuk menghitung kecepatan melajunya ETR. Dengan dibuatnya produk tersebut maka siswa akan lebih bermakna dalam memahami konsep tentang komponen listrik dan bertahan lama diingatannya. Selain itu penerapan STEM dalam pembelajaran dapat mengasah kognitif, manipulatif dan afektif (Permanasari, 2016:29). Sehingga dengan penerapan RPP ini diharapkan pembelajaran dapat disesuaikan dengan kebutuhan dalam kurikulum 2013 serta meningkatkan mutu pendidikan di Indonesia.

RPP STEM merupakan desain pembelajaran yang dirancang dengan adanya proses rekayasa oleh siswa. Proses rekayasa dapat dilihat dari kegiatan siswa pada saat merancang media sebagai keterampilan dalam penerapan pengetahuan yang didapat (Kaniawati \& Suwarma, 2015). RPP STEM dibuat dengan memperhatikan karakteristik pembelajaran berpusat pada siswa, memahami konsep dengan melakukan rekayasa, adanya literasi, serta kegiatan yang dilakukan didasari oleh keterampilan 4C. Melalui keterampilan $4 C$ dalam pembelajaran STEM diharapkan dapat memberikan pengalaman siswa berlatih membuat suatu produk yang bermanfaat bagi kehidupan siswa dikemudian hari.

104 | Jurnal Ilmiah "Pendidikan Dasar" Vol. ..... No. .... [Bulan] [Tahun] 
RPP yang dibuat peneliti dengan model STEM dalam menyusun langkah pembelajaran dapat dilakuakn berdasarkan sintaks engineering design process yang dijelaskan oleh Cunningham (2018), yakni :

1. Ask (bertanya), yaitu mengidentifikasi masalah dan batasannya.

2. Imagine (membayangkan), yaitu menggali dan memilih gagasan yang terbaik.

3. Plan (merencanakan), menggambar diagram dan mengumpulkan bahan.

4. Create (mencipta), mengikuti rencana dan mengikutinya.

5. Improve (meningkatkan), membahas kemungkinan perbaikan dan ulangi langkah 1 sampai 5.

Dari sintaks tersebut, maka pembelajaran yang dilakukan dalam RPP STEM menggunkan pendekatan terpadu yaitu adanya pengintegrasian materi pembelajaran STEM tanpa terlihat batasannya. Hal tersebut sesuai dengan tujuan STEM meurut Figiano dalam Ceylan, S. (2015) yaitu "One of the goals of STEM eduaction is to raise interdisciplinary thinkers". Kemudian dalam kegiatannya proses pembelajaran dapat menerapkan dan melatih keterampilan $4 C$, hal tersebut dapat dilihat pada Gambar 2 mengenai kegiatan inti dalam RPP melibatkan penilaian ketarampilan $4 C$.

\section{SIMPULAN}

Partisipasi guru dalam membuat rancangan pembelajaran sebelum dilakukannya proses pembelajaran di kelas masih kurang. Minimnya pemahaman guru terhadap desain pembelajaran sehingga proses pembelajaran disesuaikan dengan buku siswa yang mungkin tidak sesuai dengan karakteristik siswa di kelas. Produk RPP ini diharapkan dapat menjadi contoh dalam memberikan pengetahuan untuk menggambarkan penyusunan rancangan desain pembelajaran yang inovatif, kreatif, dan bermakna dengan menggunakan model STEM bagi guru di SD. Pembelajaran STEM erat kaitanya dengan kurikulum 2013 yang menintegrasikan beberapa mata pelajaran yaitu sains, teknik, teknologi, dan matematika yang kemudian secara teringrasi mampu meningkatkan keterampilan abad 21 yaitu 4C. Dari analisis tersebut maka pembelajaran STEM ini dirasa cocok untuk diterapkan pada pembelajaran di SD yang dilakukan secara tematik-teringrasi. Dalam menyusun desain pembelajaran digunakan RPP yang telah disesuaikan dengan pedoman Permendikbud Nomor 22 tahun 2016, dan dilakukan dengan pembelajaran STEM yang meliputi 5 tahapan dalam langkah-langkah mengajar. Tahapan tersebut yaitu menanya, membayangkan, merencanakan, membuat, dan meningkatkan. Produk RPP yang dikembangkan telah divalidasi bersama tim pengembang perangkat pembelajaran dan fasilitator pembelajaran STEM melalui kegiatan FGD. Proses rancangan/prototype secara FGD pada pembelajaran STEM diharapkan dapat dijadikan sebagai bahan referensi khususnya dalam pengembangan desain pembelajaran berupa RPP yang lebih baik untuk di implementasikan di Sekolah Dasar. 


\section{DAFTAR PUSTAKA}

Bisjoe, A. R. H. (2018). Menjaring Data dan Informasi Penelitian melalui FGD (Focus Group Discussion): Belajar dari Praktik Lapangan. Info Terkini Ebono, 15 (1), 17-28.

Bunyamin, M. A. H. (2016). Pendidikan STEM Bersepadu: Perspektif Global, Perkembangan Semasa di Malaysia, dan Langkah Kehadapan. Research Gate, 1.

Ceylan, S., \& Ozdilek, Z. (2015). Improving a Sample Lesson Plan for Secondary Science Courses Whitin the STEM Education. Social and behavioral sciences, 177, 223-228. doi: 10.1016/j.sbspro.2015.02.39

Cunningham, C.M. (2018). Engineering in Elementary STEM Education (Curriculum Design, Intruction, Learning, and Assesment). New York: Teacher College Press.

Giamellaro, M., \& Siegel, D. R. (2018). Coaching teachers to implement innovations in STEM. Teaching and Teacher Education, 76, 25-38. https://doi.org/10.1016/j.tate.2018.08.002

Glynn P, Shanahan M and Duggan D. (2015). Focus groups. Available from: https://www.slideshare.net/johnglynn940/focus-groups-presentation [Accessed on 12th November 2017]

Gofur, A. (2012). Desain Pembelajaran. Yogyakarta: Ombak (Anggota IKAPI)

Gustina, S. I. (2018). Pengembangan Desain Pembelajaran Tematik Outdoor Permainan Tradisional Berbasis STEM di Sekolah Dasar. Universitas Pendidikan Indonesia kampus Tasikmalaya.

Hamdu, G., Karlimah, \& Nursyarifah, F. (2016). Pengembangan Perangkat Pembelajaran Sebagai Implementasi Kurikurikulum 2013. Prosiding Seminar Nasional Pendidikan Sains, 375-380.

Ibrahim. (2017). Perpaduan Model Pembelajaran Aktif Konvensional (ceramah) dengan Cooperatif (make-a match) untuk Meningkatkan Hasil Belajar Pendidikan Kewarganegaraan. Suara Guru: Jurnal Ilmu Pendidikan Sosial, Sains, Dan Humaniora, 3(2), 199-212.

Indrizal, E. (2014). Diskusi Kelompok Terarah. Journal Antropologi: Isu-Isu Sosial Budaya, 1, 75-82.

Kaniawati, D. S., \& Suwarma, I. K. I. R. (2015). Study Literasi Pengaruh Pengintegrasian Pendekatan STEM dalam Learning Cycle 5E terhadap Kemampuan Pemecahan Masalah Siswa pada Pembelajaran Fisika. PROSIDING, 39.

Khoiriyah, N., Abdurrahman, \& Wahyudi, I. (2018). Implementasi pendekatan pembelajaran STEM untuk meningkatkan kemampuan berpikir kritis siswa SMA pada materi gelombang bunyi. JRKPF UAD, 5(1), 53-62. 
Kosasih, E. (2018). Strategi Belajar dan Pembelajaran Implementasi Kurikulum 2013. Bandung: Yrama Widya

Kristien, A. (2019). STEM Learning at NYPi Singapore as an Inspiration for Education in Indonesia. Ideguru: Jurnal Karya Ilmiah Guru, 4(1), 1-11

Lidinillah, D., Mulyana, E., Karlimah, K., \& Hamdu, G. (2019). Integration of STEM learning into the elementary curriculum in Indonesia : An analysis and exploration Integration of STEM learning into the elementary curriculum in Indonesia : An analysis and exploration. Journal of Physics, 1-7. https://doi.org/10.1088/1742$6596 / 1318 / 1 / 012053$

Musnidar, L. (2018). Pengaruh Penerapan Pembelajaran Stem ( Science, Technology, Engineering , Mathematics ) Terhadap Keterampilan Creatif Problem Solving Dan Komunikasi Siswa. Prosiding SEMNAS MIPA IV, 174-179.

National Education Association. (2010). Preparing 21st Century Skills for a Global Society: An education guide to the "four Cs". Retrieved April 26, 2020, from National Education Association: http://www.nea.org/assets/docs/A-Guide-to-Four-Cs.pdf

Nurlenasari, N., Lidinillah, D., Nugraha, A., \& Hamdu, G. (2019). Assessing 21 st century skills of fourth-grade student in STEM learning. IOP Conf. Series: Jurnal Of Physics, 1-7. https://doi.org/10.1088/1742-6596/1318/1/012058

Omar, D. (2018). Focus group discussion in built environment qualitative research practice. IOP Conference Series: Earth and Environmental Science, 117(1). https://doi.org/10.1088/1755-1315/117/1/012050

Paramita, A. (2013). Focus group discussion. Buletin Penelitian Sistem Kesehatan, 16, 117-127.

Permanasari, A. (2016). STEM Education : Inovasi dalam Pembelajaran Sains. Prosising Seminar Nasional Pendidikan Sains (SNPS), 23-34.

Putra, D. M., \& Nurlizawati, N. (2019). Lesson Study dalam Meningkatkan Keterampilan 4C (Critical Thingking, Collaborative, Communicative dan Creative) pada Pembelajaran Sosiologi yang Terintegrasi ABS-SBK di SMAN 1 Pasman. Jurnal Sikola: Jurnal Kajian Pendidikan dan Pembelajaran, 1(2), 139-146.

Sukmana, R. W. (2017). Pendekatan Science, Technology, Engineering and Mathematics (STEM) sebagai Alternatif dalam Mengembangkan Minat Belajar Peserta Didik. Pendas: Jurnal Ilmiah Pendidikan Dasar, II, 191-199.

Torlakson, T. 2014. INNOVATE: A Blueprint for Science, Technology, Engineering, and Mathematics in California Public Education. California: California Department of Education.

Uno, H. B. (2006). Orientasi Baru Dalam Psikologi Pembelajaran. Jakarta: Bumi Aksara. 
Widoyoko, S. E. P. (2008). Penerapan Sertifikasi Guru dalam Meningkatkan Mutu Pendidikan. In Seminar Nasional Peningkatan Mutu Pendidikan melalui Sertifikasi Guru. Universitas Muhammadiyah Purwerejo.

Zubaidah, S. (2016). Keterampilan Abad ke-21: Keterampilan yang diajarkan melalui pembelajaran. In Seminar Nasional Pendidikan dengan tema "Isu-isi Strategis Pembelajaran MIPA Abad, 21(10) 